\title{
Standardize Input, Personalize Output: Catering to the Needs of All Students in the Multi-Level Classrooms of East Asia
}

\author{
Todd Hull* \\ Assistant Professor, Department of English, Hankuk University of Foreign Studies, Seoul, South Korea \\ *Corresponding Author: Todd Hull, Assistant Professor, Department of English, Hankuk University of \\ Foreign Studies, Seoul, South Korea
}

\begin{abstract}
A common dilemma in the EFL/ESL classroom is what to do with classes in which there are learners of differing abilities. This problem takes a different form in university English programs in East Asia than in the ESL classrooms of North America, Britain and elsewhere in that the learners in the basic communicative English programs that are common for freshmen in East Asia are "false beginners." They have had a fair amount of English instruction prior to entering university. Further, as a result of the similar curricula in their pre-university educations, not only do students come to class with knowledge of English, but they come with similar knowledge bases in terms of grammar and vocabulary. This paper proposes a method for dealing with diverse levels in these learning environments in which educators make use of students' passive knowledge for receptive skills and allow learners to create their own material for productive output.
\end{abstract}

Keywords: Multi-Level Classrooms; Comprehensible Input; Productive Output; Fluency; Learner Needs; Differentiated Instruction; Individualized Instruction; Student-Generated Material

\section{INTRODUCTION}

Addressing the needs of all learners in the classroom, rather than just teaching to the top of the class is incumbent on all educators. An aspect of that mandate that manifests itself in the EFL classroom is attending to the needs of students of differing competencies in English who are in the same class. The challenges of multi-level classrooms differ according to each individual learning situation. In ESL contexts learners may be in-country arrivals from various cultures arriving for different reasons and with widely varying proficiencies in English. Sometimes the individual needs of all students in these learning contexts are not met. "Some programs (generally because of funding constraints, learner scheduling difficulties, number of learners, and program logistics) place learners of all levels, from beginning to advanced, in a single class." (Shank and Terril, 1995) In the EFL context, situations range from learners attending evening and weekend classes that take all comers (sometimes in circumstances similar to those mentioned by Shank and Terrill above) to language academy and university programs that institute placement tests to group students according to ability. The focus of this paper will be on East Asia, specifically universities in Japan and South Korea where students enter university with relatively uniform exposure to English in their primary and secondary school education.

In contrast to a large number of ESL students who are "literacy learners," defined as those who " are generally those with 6 or fewer years of education in their native countries who need focused instruction on learning to read and write English" (Cunningham Florez 2003), students entering university in East Asia are, like many students, "false beginners" in that they have not only completed education through high school, but have studied English before starting university. They do not fall into the categories delineated by Cunningham Flores as preliterate, nonliterate, semiliterate, Nonalphabet literate, or Non-Roman alphabet literate, learners who "need to understand that texts have a beginning, a middle, and an end; that English is read from left to right and from up to down; and that written words can represent a story, just as pictures do." (Cunningham Florez 2003)

This is what differentiates University students in the EFL contexts of Japan and South Korea from the ESL circumstances of many other learners who have had some exposure to English: they have gone through a relatively standardized English curriculum in elementary, middle, and high school. So students in Japan and South Korea come into the university classroom with similar exposures to 
English. But just because these students have gone through similar curricula does not mean they are all at the same level when it comes to English proficiency, especially in the productive skills of speaking and writing. University students in Japan and South Korea have very similar abilities when it comes to receptive skills. They can understand both written and spoken input with similar levels of success. And they have quite advanced vocabularies as a result of the focus on vast lists of lexical items they were required to memorize in their pre-university schooling. It is in the productive skills of writing, and especially speaking, where their differences are more apparent. Two learners may breeze through a given text with similar success. But when asked to elaborate on it in a written or spoken response, their differences emerge. Catering to these differences is the focus of this article.

\section{LITERATURE REVIEW}

Attending to the needs of individual learners within a class is often referred to as differentiated instruction, which is "an approach that enables teachers to plan strategically to meet the needs of every student. It is rooted in the belief that there is variability among any group of learners and that teachers should adjust instruction accordingly." (Corley 2005) What are some of the theoretical underpinnings for the efficacy of this type of instruction?

Individualized instruction addresses the needs not only of students of differing levels and different learning styles, but also of those who learn according to the individual ways in which they intellectualize the world and how they assimilate information they are exposed to as conceived of by Harvard University psychology professor, Howard Gardner in his now classic 1983 book, Mind in Society: The Development of Higher Psychological Processes. In it Gardner takes issue with the notion of a single standard of intelligence defined narrowly as prowess in "book learning," which privileges those who excel in traditional academic environments Instead, he proposes that there are "multiple intelligences," proclivities which include a far greater range than academic success as it is commonly perceived, which is basically defined as how well students do in a traditional school environment. Individualized instruction allows each student in a classroom to engage the material according to how they best assimilate and utilize knowledge they are exposed to.

Also, research (Ellis 1999) suggests that learners learn better when they are in charge of topics they address in the classroom and also over the nature of the discourse they engage in. In some contexts, allowing students to choose the topics they will cover or creating a negotiated syllabus results in an optimal learning environment. In the classrooms of Japan and South Korea, though, the most effective classroom environment is generally created when the instructor chooses the topics and the forms of written output the students will be asked to produce but allows the learners to control the productive output. As Dana Moss (2005) puts it, "the teacher is the initiator of interaction. That does not mean that the teacher is always in control of the discourse."

Finally, Merrill Swain (Swain 1995) has argued that lower level learners develop greater proficiency when interacting with higher level learners. Research (Watanabe and Swain 2007) has supported her hypothesis and a great number of second language educators have made higher/lower level groupings a part of their classrooms.

\section{Commonly USEd Classroom STRATEgies for Multi-LeVel Learners}

Probably the most common strategy for dealing with multi-level classes is grouping learners according to their abilities, dividing lower level and higher level learners into different groups and having them study together. "The use of grouping strategies can form the basis for the multilevel class as teachers mix and match groups, pair learners, and allow time for individual or solo activities during each class period." (Shank and Terril 1995)

Some teachers may find it useful to group students according to things other than ability in the target language. It may be effective to group students according to cultural background to smooth social interactions within the group. This can be useful for learners who come from cultures where age is a fundamental factor in interpersonal relations. If this method is utilized, students of similar ages can be grouped together to make interactions easier. It can also be of assistance for students whose cultures have structured interactions between the sexes to group students according to gender.

Another method for dealing with the difficulties associated with multi-level classes is tailoring materials to individual learners. This is most effective with self-access materials that are given to 
students to study individually, either during or outside of class. "When learners are doing independent or solo activities in the multilevel classroom, using self-access materials can enable them to take responsibility for choosing work appropriate to their individual levels and interests." (Shank and Terril 1995)

In addition to planning the types of materials that will serve the needs of all students in multi-level classrooms, another challenge for educators is how to most effectively manage the classroom once studying is underway. One method for this is whole class instruction in which the teacher provides guidance to the entire class on how to proceed and then rotating around the class to provide instruction to groups. Another strategy is to employ different types of peer learning, including "peer tutors" within groups, and even students circulating and assisting other groups as peer tutors. (Shank and Terril 1995)

But difficulties and challenges are not the only things multilevel classrooms are made of. There are also benefits. As was mentioned above, research suggests that lower level learners benefit from interactions with their higher level peers. Higher level learners push those at a lower level towards greater proficiency, both in listening and speaking. Also, higher level learners (especially when teachers specifically thank them for helping lower level learners) feel a sense of accomplishment and pride in being able to help their classmates, which provides motivation for them to continue having interactions with learners who may not push their abilities.

Also, group and pair work not only benefits learners' language proficiency, but enhances analytical skills such as those required for proficiency tests like the GED and TOEFL. An instructor at an adult learning center in the U.S. remarked that when many students first encounter these tests, "they still try to look for answers directly stated in passages. Making inferences and drawing conclusions are higher-level thinking skills. Group work is a wonderful way to develop these skills." (The Best of Both Worlds, 2005)

\section{Classroom Applications: Catering to Multi-level Learners in the EFL ClASSROOMS OF EAST ASIA}

Differentiated instruction, as with any form of instruction, should be based on the needs of the learners in a specific learning environment, ideally after a detailed needs analysis is conducted (Brown 1995). As was mentioned before, unlike many ESL classrooms, which are composed of learners of varying backgrounds and radically different abilities in the target language, students in the universities of East Asia, specifically Japan and South Korea, enter the classroom with a relatively uniform exposure to English as a result of nationally standardized curricula in their primary schooling. Further, English education in these countries focuses disproportionately on the receptive skills of reading and listening, as well as on memorizing a large number of lexical items required for tests given at the end of high school. As a result, most students will be able to comprehend and profit from reading that is at a relatively high level, even if their ability to elaborate on that material in the productive channels of speaking and writing shows more variance than in their receptive skills. This means that texts at a fairly high level of difficulty can be assigned to a class and that the vast majority of learners in that class will be able to negotiate them.

The method for addressing the needs of multi-level classes advocated in this article is to choose receptive material accessible yet challenging to the majority of students in the class and then allow productive material to be student-generated. In short, standardize receptive material; personalize productive material.

For example, the teacher might assign the topic of renewable energy for classroom discussion. The output portion of student engagement of the material would specify the type of written output (e.g. an opinion paragraph, a reasons/examples paragraph, a letter to the editor, etc.). After the students complete the assigned written output, they discuss the topic in any way they see fit. Some students may choose to go point by point through their opinion on the topic. Others may give a general summary and seek input from their interlocutor. Others may go about it differently. There are a number of ways in which students may direct their discourse, but the most important thing is getting students to engage the topic in the target language. Allowing the freedom for learners to go about that in the way that best speaks to their individual learning styles is the goal in this type of instruction. 
Before outlining how to apply this in the classroom, a quick note about whether to use "authentic" material drawn unedited from primary sources or summaries of that material crafted to be more readily accessible to learners in the classroom is in order. There is a school of thought that advocates a position that input should come from "authentic" sources not altered or edited in any way for learners. Altering the material, according to this opinion, could sacrifice the native-speaking status of the material and render it "unnatural" and thus unproductive for students' studies.

A more compelling argument comes from linguist and educator Henry Widdowson (Widdowson 2002) who stated in a lecture that "language learning behavior is not necessarily the same as language using behavior." [Emphasis in original] This is in accordance with the principle of scaffolding, which provides learners with assistance on their way to being able to negotiate texts in their original and ultimately to be able to interact with others proficiently in the target language. Original texts harbor the danger of intimidating students and putting them off engaging the material. Hours spent with dictionaries in an attempt to get a handle on the text is also valuable time wasted. It is a much more pedagogically sound decision to provide students with material that contains all the important information from the original without all the debilitating distractions and difficulties original texts can pose to students, in other words, to provide students with comprehensible input rather than a frustrating barrage of incoming complexity. The example lesson given here will embrace this "sheltered learning" idea as the one which is most beneficial to students.

\section{EXAMPLE LESSON}

The following is a practical example of how this can be implemented in the classroom. The source material summarized and given to students is the last chapter of the second edition of Air Pollution and Global Warming: History, Science, and Solutions, a textbook by Stanford University professor, Mark Z. Jacobson in which he explains the drawbacks of current methods of providing energy to the world and the advantages and disadvantages of various proposed solutions. (See Appendix A for the summary used as the material students engage for the lesson.)

Ideally, the material is given to students a few days before the lesson in which they will work with it, along with some comprehension questions for homework. This helps students focus on the main points of the material so that they can understand it better. Depending on the class, instructors can choose how to deal with the homework. They can check it and give credit for it (or deduct points for homework not completed); they can make the homework optional but suggested and circulate around the class and check it (both to see how many students actually did it and maybe to give students encouragement to do it if they know it will be checked, however informally); or they can make it purely optional and not check it at all, just noting that doing the homework will help the students when they are tested on the material or have to use it for other evaluative purposes at a later date. It depends on the learners in the classroom and the priorities of the teacher.

The next step is to go over the answers to the comprehension question homework which highlights the main points of the material that will be used in class. This can serve as the "lecture" portion of class and is often more effective than a traditional lecture format - especially in the EFL context - because the "lecture" is broken up into smaller pieces that center around individual comprehension questions about the text. This makes it not only more digestible for students, but gives them specific points of focus rather than a long lecture which they might not organize as well in their note-taking as they might by addressing specific questions about specific points in the material.

That is the standardized input. All the students receive the same material (and can process it successfully because of the context of their pre-university education discussed above). After working with the input, the output phase takes the form of students reacting to the material, both in written and spoken formats. This is where the personalization comes in. Students react to the standardized input with their own personalized output, which each student completes at their own level of proficiency. This can be in any format instructors deem appropriate for the learners in their classes. Students can just have a discussion with a partner about their reaction to the text. They can make some brief notes and then present their opinions to a partner or in a small group, who can then discuss it. Or it can be more formal and structured. Students might write an organized paragraph-opinion, reasons/examples, cause/effect, opinion with counterargument, or any other format the instructor might wish to practice. They can then discuss their writings with a partner, have partner's peer review 
their writing, or other interactions that would provide students chances to enhance their language ability. The output could even take the form of practice writing for the written parts of standardized proficiency tests like the TOEFL or IELTS. The important thing is that each student is only asked to produce according to their ability. No student is pressured to produce at levels above which they can comfortably negotiate, thus raising Krashen's affective filter and impeding communication

Personalized output also has other advantages, both linguistic and motivational. It allows students to create their own material in the target language, which research (DeKeyser, 1998 and Ellis 2003) shows to be more effective for retainment of knowledge than commonly used classroom practices like memorizing, drilling, and even communicative practice after presentation of a language point. Personalized output also represents what individual students are interested in, the aspects of the text they personally wish to engage, rather than a generic task set by an instructor or prescribed by a textbook. Finally, if students discuss their ideas with multiple partners, it builds fluency in the manner of the 4-3-2 activity made famous by Paul Nation (Nation 2001).

\section{CONCLuSion}

In the context of the East Asian classrooms of Japan and South Korea where students enter the classroom with a relatively uniform exposure to English in their pre-university education, meeting the needs of learners can profitably be done by utilizing their prior knowledge of the language when designing texts for classroom input and catering to differing levels of productive ability by allowing students to generate their own personalized output.

\section{REFERENCES}

[1] Balliro, L. (1997) Multiple levels, multiple responsibilities. Focus on Basics, l(C). Retrieved from http:// www.ncsall.net/index.html@id=444.html

[2] Brown, H.D. (2001). Teaching by principles: An interactive approach to language pedagogy (2nd ed.). White Plains, NY: Longman.

[3] Brown, J.D. (1995). The elements of language curriculum. Boston, MA: Heinle.

[4] Burt, M. (1997) The multilevel umbrella. Focus on Basics, l(C). Retrieved from http://www.ncsall. net/index.html@id=442.html

[5] Corley, M.A. (2005) Differentiated instruction. Focus on Basics, 7(C), 13-16. Retrieved from http://www. ncsall.net/index.html@id=444.html

[6] Cunningham Florez, M. (2003 July) Working with literacy-level adult english language learners. Retrieved from http://www.cal.org/caela/esl_resources/digests/litQA.html

[7] DeKeyser, R. (1998). Beyond focus on form: Cognitive perspectives on learning and practicing second language grammar. Focus on form in classroom second language acquisition, C. Doughty \& J. Williams (Eds.). Cambridge, UK: Cambridge University Press.

[8] Ellis, N.C. (2003). Words in mind and brain: Implications for vocabulary acquisition and instruction. Seminar on Vocabulary Acquisition at Temple University, Tokyo, Tokyo, Japan, January 25-26, 2003.

[9] Ellis, R. (1997). SLA research and language teaching. Oxford, UK: Oxford University Press.

[10] Ellis, R. (1999). Learning a second language through interaction. Philadelphia, PA: John Benjamins.

[11] Gardner, H. (1983/2011). Mind in society: The development of higher psychological processes. New York, NY: Basic Books

[12] General strategies for managing a multilevel classroom. Retrieved from https://niceclasses.jimdo.com/ resources/managing-a-multilevel-class/

[13] Harmer, J. (2007). How to teach english. Essex, UK: Pearson/Longman.

[14] Hess, N. (2001). Teaching large multilevel classes. New York, NY: Cambridge University Press.

[15] Jacobson, M.Z. (2012). Air pollution and global warming: History, science, and solutions (2 ${ }^{\text {nd }}$ ed.). New York, NY: Cambridge University Press.

[16] Moss, D. (2005). Teaching for communicative competence: Interaction in the ESOL Classroom. Focus on Basics, 7(C). Retrieved from http://www.ncsall.net/index.html@id=739.html

[17] Nation. P. (2001). Learning vocabulary in another language. Cambridge University Press.

[18] Roberts, M. (2007). Teaching in the multilevel classroom. http://www.pearsonlongman.com/ae/download/ adulted/multilevel_monograph.pdf

[19] Saldana, C. (2005) Differentiating instruction for a multilevel class. Focus on basics, 7(C), 17-18. Retrieved from http://www.ncsall.net/index.html@id=735.html 
[20] Shank, C.C. \& Terrill, L.R. (1995). Teaching multilevel adult ESL classes. ERIC Digest ED383242. Washington, DC: National Clearinghouse for ESL Literacy Education. Retrieved from http://www.eric digests.org/1996-1/adult.htm

[21] Swain, M. (1995). Three functions of output in second language learning. In G. Cook \& B. Seidhofer (Eds.), Principle and practice in applied linguistics: Studies in honor of H.G. Widdowson. Oxford, UK: Oxford University Press.

[22] The best of both worlds: Using individualized and group Instruction (2005, March). Focus on basics, 7(C), 19-23. Retrieved from http://www.ncsall.net/index.html@id=735.html

[23] Watanabe, Y. \& Swain, M. (2007). Effects of proficiency differences and patterns of pair interaction on second language learning: Collaborative dialogue between adult ESL learners. Language teaching research 11:2, 121-142.

[24] Widdowson, H. (2002). The language we teach. Keynote speech. JALT conference.

\section{APPENDIX A}

Summary of the last chapter of Mark Z. Jacobson's Air pollution and global warming: History, science, and solutions ( $2^{\text {nd }}$ ed.), "Energy Solutions to Air Pollution and Global Warming."

\section{Mark Z. Jacobson on Solutions to Air Pollution ANd Global Warming}

Professor Jacobson advocates "the complete, large-scale conversion of the current...[fossil fuel] energy structure to one based on" renewable resources. He calls his plan WWS because the majority of the power would come from wind, water, and sun. He also recommends geothermal as a significant source of power, and that tidal power is a good option in some countries. Jacobson says that with effort and political will, this can be achieved by sometime between 2030 and 2050 .

Before giving the details of his WWS plan, Professor Jacobson addresses one of the most common questions he is asked when presenting his plan for the world's energy future: "Why not Nuclear Energy?" His first reason for not including it in his plan is that nuclear energy has often gone hand in hand with the development of nuclear weapons. He also points to the fact that the refining and transport of uranium result in "nine to twenty-five times more...emissions...than wind." He also says that nuclear power plants take so long to build that any carbon emissions reduced by their power generation are offset both by the emissions required for their construction and also by the $\mathrm{CO} 2$ emitted by fossil fuel used during the long years of their construction. He also references disasters like Fukushima that would not occur in a non-nuclear electricity generation environment. Finally, he mentions that there is no safe way to dispose of the radioactive waste that nuclear facilities create.

He then goes on to explain why other solutions are also problematic. In addition to problems with "capturing" emissions, Coal with carbon capture (CCS) plants require " 25 percent more energy to operate than does a conventional coal plant." That, combined with the fact that mining and transporting coal are highly polluting processes, makes it such that a CCS plant "emits about fifty times more $\mathrm{CO} 2$ than does a wind farm producing the same quantity of electric power." Natural gas is also problematic according to Jacobson. While it is a bit cleaner than coal and oil, emissions associated with its production and use are far higher than WWS and geothermal. It also takes vast amounts of water to produce shale gas from fracking, something which can be a significant problem in places prone to drought, like the state of California. Finally, he talks about problems with biofuels. Their cultivation also takes vast amounts of water and results in the destruction of natural habitats to make way for biofuel crops. And some of them are not significantly less polluting than fossil fuels.

After pointing out the problems with those solutions, Jacobson outlines his WWS plan. The first "W" in the plan is for wind power, which he points to as the major source of clean energy for the world. He references a UN study that found that fully $500 \%$ of the world's current energy needs could be provided by wind power alone. He also provides tables and statistics showing that the " $\mathrm{S}$ " in his plan, solar can provide significant amounts of energy. He is not as enthusiastic about the other "W" in his plan, water, because the environmental devastation wrought be hydroelectric dams is a serious problem, and dam accidents can be catastrophic. So he recommends using mostly existing hydroelectric and increasing the number and quality of turbines on dams to increase electricity output. He discourages the construction of most new dams, saying that only existing dams and small-scale ones that pass thorough environmental review would be part of his plan. 
Near the end of the chapter in a section entitled, "Reliably Matching Demand with Variable Wind, Water, and Sunlight Resources," Jacobson takes on the most common objection to getting power from clean, renewable sources like the sun and wind - that it is intermittent, that there's no power when the sun isn't shining and the wind isn't blowing. He suggests several ways that WWS can provide a stable, reliable power grid: 1) Build a smart grid to interconnect power sources across geographical distances; 2) Combine wind and solar with other sources like geothermal and tidal; 3) Store electric power (e.g. in large batteries) at the sites of wind and solar generation for use when needed; 4) Have solar and wind facilities produce more power than needed to produce hydrogen for hydrogen fuel cells that can be used as power sources when necessary; and 5) store power in vehicle batteries. When these batteries are plugged in, they can provide power to the grid.

Professor Jacobson says that if all those solutions are implemented, the world can be powered by clean, renewable energy and that we won't need the dirty, dangerous, and destructive power sources of the past.

Citation: Todd Hull. "Standardize Input, Personalize Output: Catering to the Needs of All Students in the Multi-Level Classrooms of East Asia". International Journal on Studies in English Language and Literature (IJSELL), vol 6, no.10, October 2018, pp. 1-7. doi:http://dx.doi.org/10.20431/2347-3134.0610001.

Copyright: (1) 2018 Authors. This is an open-access article distributed under the terms of the Creative Commons Attribution License, which permits unrestricted use, distribution, and reproduction in any medium, provided the original author and source are credited. 